\title{
URANS simulations of separated flow with stall cells over an NREL S826 airfoil
}

\author{
Sarlak Chivaee, Hamid; Nishino, T.; Sørensen, Jens Nørkær
}

Published in:

AIP Conference Proceedings

Link to article, DOI:

$10.1063 / 1.4951795$

Publication date:

2016

Document Version

Publisher's PDF, also known as Version of record

Link back to DTU Orbit

Citation (APA):

Sarlak Chivaee, H., Nishino, T., \& Sørensen, J. N. (2016). URANS simulations of separated flow with stall cells over an NREL S826 airfoil. AIP Conference Proceedings, 1738, [030039]. https://doi.org/10.1063/1.4951795

\section{General rights}

Copyright and moral rights for the publications made accessible in the public portal are retained by the authors and/or other copyright owners and it is a condition of accessing publications that users recognise and abide by the legal requirements associated with these rights.

- Users may download and print one copy of any publication from the public portal for the purpose of private study or research.

- You may not further distribute the material or use it for any profit-making activity or commercial gain

- You may freely distribute the URL identifying the publication in the public portal

If you believe that this document breaches copyright please contact us providing details, and we will remove access to the work immediately and investigate your claim. 


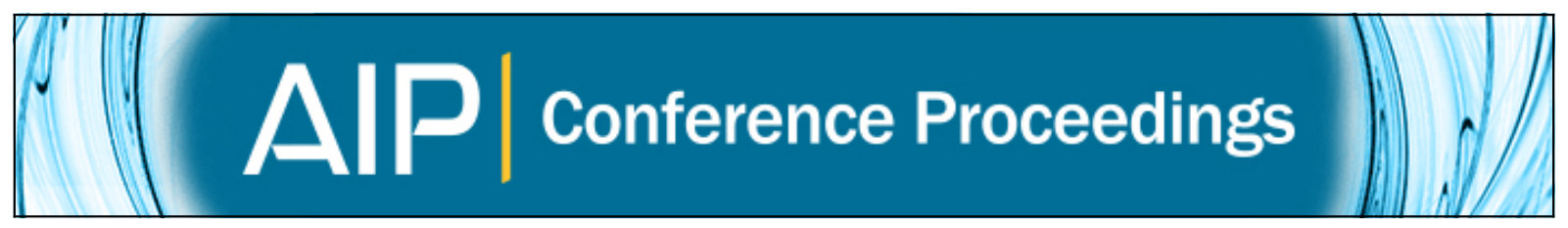

\section{URANS simulations of separated flow with stall cells over an NREL S826 airfoil}

H. Sarlak, T. Nishino, and J. N. Sørensen

Citation: AIP Conference Proceedings 1738, 030039 (2016); doi: 10.1063/1.4951795

View online: http://dx.doi.org/10.1063/1.4951795

View Table of Contents: http://scitation.aip.org/content/aip/proceeding/aipcp/1738?ver=pdfcov

Published by the AIP Publishing

Articles you may be interested in

A direct numerical simulation investigation of the synthetic jet frequency effects on separation control of low-Re flow past an airfoil

Phys. Fluids 27, 055101 (2015); 10.1063/1.4919599

CFD investigation of effects of wind tunnel walls on flow properties over S809 airfoil

AIP Conf. Proc. 1547, 727 (2013); 10.1063/1.4816926

Control of Stall Flow over Airfoil using Vortex Generators

AIP Conf. Proc. 1376, 203 (2011); 10.1063/1.3651876

Discrete conservation principles in large-eddy simulation with application to separation control over an airfoil Phys. Fluids 20, 101515 (2008); 10.1063/1.3006077

Fluctuating pressures in jet flows over airfoil surfaces

J. Acoust. Soc. Am. 59, S32 (1976); 10.1121/1.2002638 


\title{
URANS Simulations of Separated Flow with Stall Cells over an NREL S826 Airfoil
}

\author{
H. Sarlak*, T. Nishino ${ }^{\dagger}$ and JN. Sørensen** \\ *Fluid Mechanics Section, Department of Wind Energy, Technical University of Denmark, Denmark, \\ hsar@dtu.dk. \\ ${ }^{\dagger}$ Centre for Offshore Renewable Energy Engineering, Cranfield University, UK. \\ ${ }^{* *}$ Fluid Mechanics Section, Department of Wind Energy, Technical University of Denmark, Denmark
}

\begin{abstract}
A series of wind tunnel measurements and oil flow visualization was recently carried out at the Technical University of Denmark in order to investigate flow characteristics over a 14\% thick NREL S826 airfoil at low Reynolds numbers. This paper aims at presenting numerical simulations of the same airfoil using unsteady Reynolds-averaged Navier-Stokes (URANS) approach. Results of the simulations are demonstrated in terms of mean flow velocity, lift and drag, as well as pressure distribution, and validated against available experimental data. The simulations are carried out with a wide computational domain (with a span-to-chord ratio of 5) and it is illustrated that the URANS approach is capable of predicting 3D spanwise structures, known as stall cells.
\end{abstract}

Keywords: Stall Cells, Mushroom Structures, Flow Visualization, URANS

PACS: 47,88

\section{INTRODUCTION}

Transitional flows around curved or inclined surfaces are among industrially relevant topics which are still not fully understood, due to the appearance of laminar separation and spanwise mushroom structures. Transitional flows associated with separation appear for instance on compressor blades, Micro-Air Vehicles, and small household wind turbines. While laminar separation has been investigated using both experiments and numerical simulations, characterization of mushroom structures around airfoil surface at low Reynolds numbers has been mostly conducted experimentally $[1,2,3,4,5]$.

On the suction side of an airfoil at low Reynolds numbers where the flow experiences an adverse pressure gradient, the boundary layer undergoes laminar separation followed by generation of unsteady Kelvin-Helmholtz vortex structures, which eventually break down to turbulence and re-attachment, forming the separation bubble. The turbulent boundary layer remains attached to the surface and withstands the adverse pressure gradient some distance downstream until turbulent separation occurs at high angles of incidence [3]. A schematic diagram of these flow phases over the airfoil is shown in figure 1.

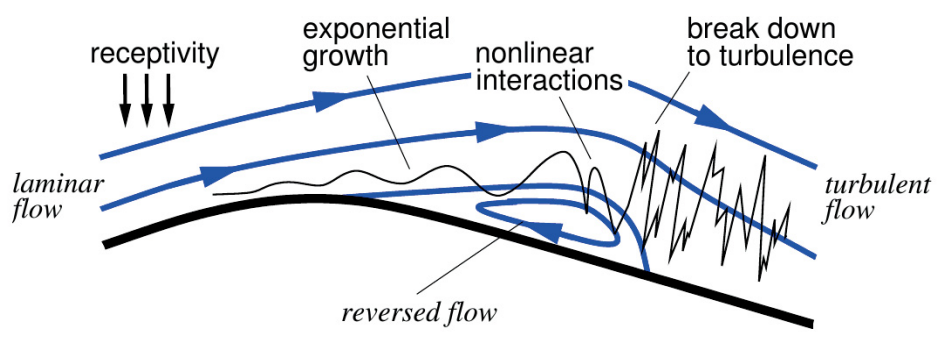

FIGURE 1. Sketch of the laminar separation bubble formed over the airfoil surface [6].

The S826 airfoil has recently been investigated experimentally as well as through LES and RANS simulations [7, 8]. In the present work we study separation associated with the stall cells by performing unsteady RANS simulations of flow structures around an NREL S826 airfoil using Menter's Shear-Stress-Transport (SST) k- $\omega$ turbulence model [9]. The simulations are compared with available wind tunnel measurements [10]. 


\section{MATHEMATICAL MODELING}

For the computations, the unsteady RANS equations are solved employing Menter's SST k- $\omega$ model [9] to close the system of equations. This two-equation eddy-viscosity model maintains the benefits of the original $\mathrm{k}-\omega$ formulation in the inner part of the boundary layer (close to a solid wall) without explicit wall modeling. In the free-stream, the model switches to the popular k- $\varepsilon$ formulation which hampers the sensitivity of the model to the inlet turbulence boundary conditions. The model has been widely used in industrial applications due to its strength in handling flows with adverse pressure gradient and separation $[9,11,12]$.

Simulations are performed using a C-mesh surrounding the airfoil, and extending 10c (c is the chord length) from pressure and suction sides as well as the wake region. The first cell center over the airfoil surface is placed at a nondimensional height of $y^{+} \approx 1$. A laminar uniform velocity is applied at the inlet and periodic boundary conditions are applied at the lateral boundaries. A non-dimensional time step of $t^{*}=t \cdot U_{0} / c=0.1$ is used and simulations are performed for 5000 time steps.

\section{RESULTS AND DISCUSSION}

This section presents results of the numerical simulations. Figures 2 and 3 show snapshots of the mean streamwise velocity contours for three different Reynolds numbers at angles of attack $\alpha=0^{\circ}$ and $12^{\circ}$, respectively. As can be seen, the flow structures are very similar for all three Reynolds numbers at the fully attached cases of $\alpha=0^{\circ}$, whereas there are some differences in $\alpha=12^{\circ}$ cases between $\mathrm{Re}=40,000$ and the two higher Reynolds numbers.

a)

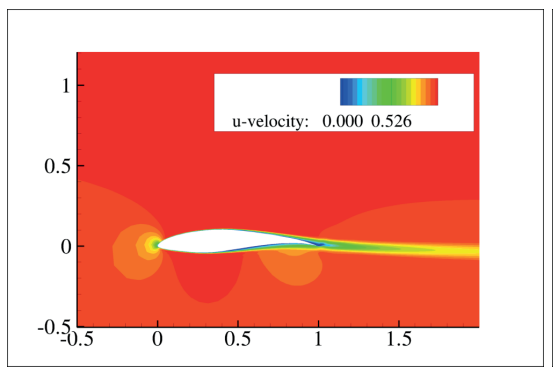

b)

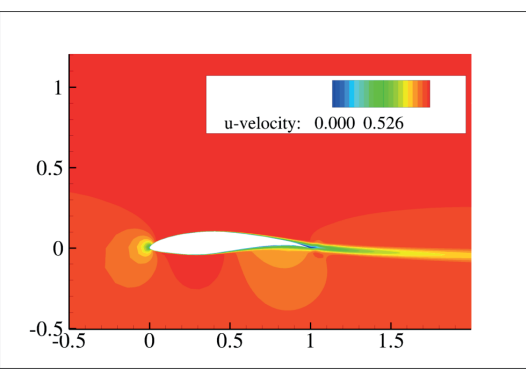

c)

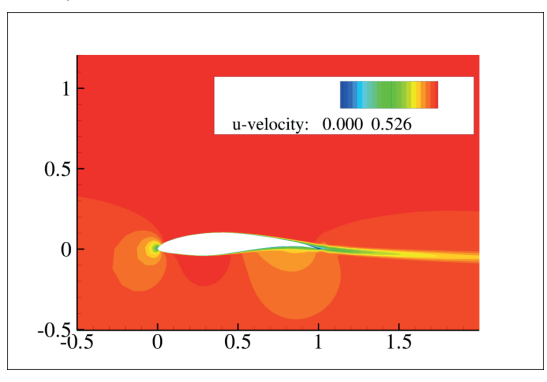

FIGURE 2. Mean streamwise velocity contours at $\alpha=0^{\circ}$ for different Reynolds numbers. (a) $\operatorname{Re}=40,000,(\mathrm{~b}) \mathrm{Re}=100,000$, (c) $\operatorname{Re}=200,000$.

a)

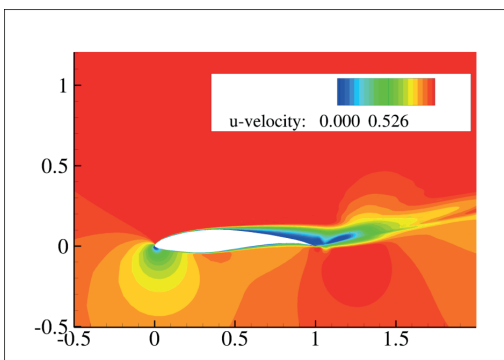

b)

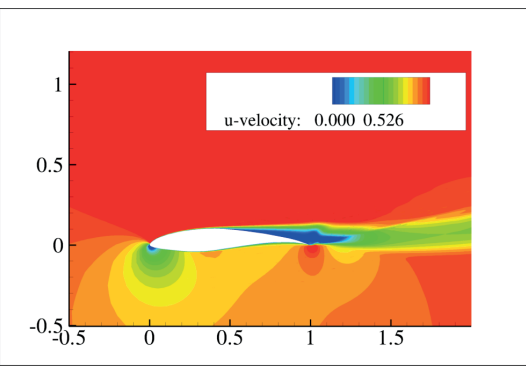

c)

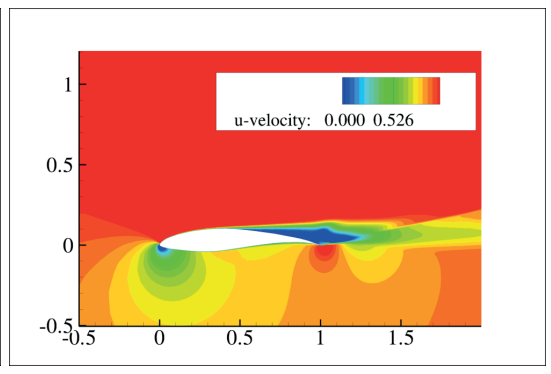

FIGURE 3. Mean streamwise velocity contours at $\alpha=12^{\circ}$ for different Reynolds numbers. (a) $\operatorname{Re}=40,000,(\mathrm{~b}) \mathrm{Re}=100,000$, (c) $\mathrm{Re}=200,000$.

Figures 4 and 5 show a comparison of the lift and drag coefficients with respect to the available measurements [10]. Interestingly, the measurements show large differences in CL and CD between the lowest Reynolds number $(\mathrm{Re}=40,000)$ and the two higher Reynolds numbers for a wide range of $\alpha$, whereas the URANS simulations do not capture such a strong effect of the Reynolds number except for the case with $\alpha=12^{\circ}$. Overall, there is a good agreement between the simulations and measurements at lower angles of attack (except for the lowest Reynolds number case). However, there are large discrepancies at higher angles of attack. 


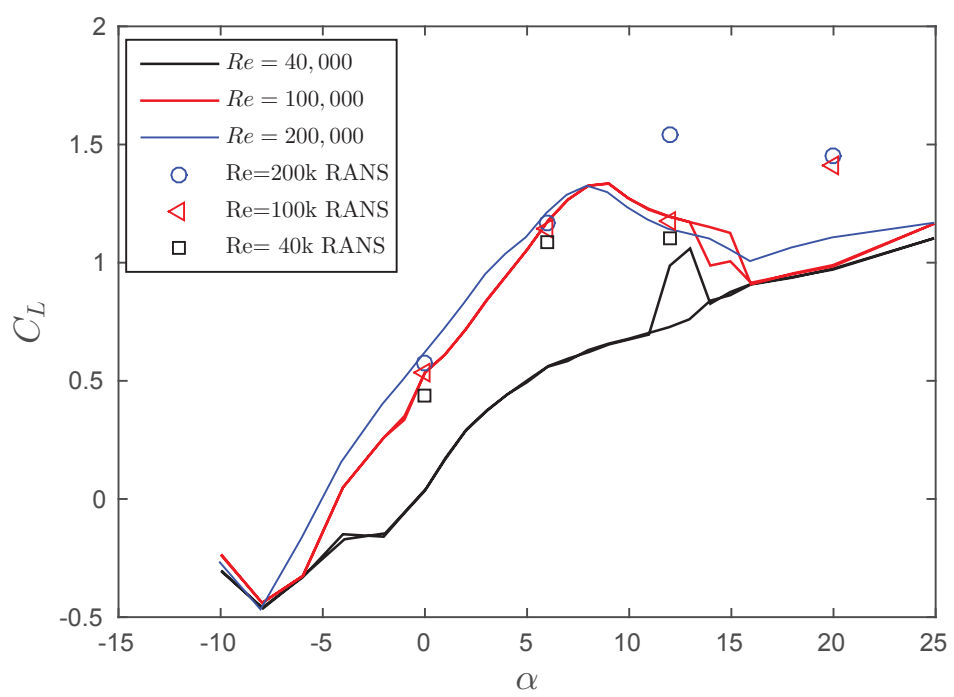

FIGURE 4. Comparison of (time-averaged) lift coefficients with experimental data [10]. Different experimental values at certain AOAs shown by the red and black curves are due to the hysteresis effects of the pitching airfoil.

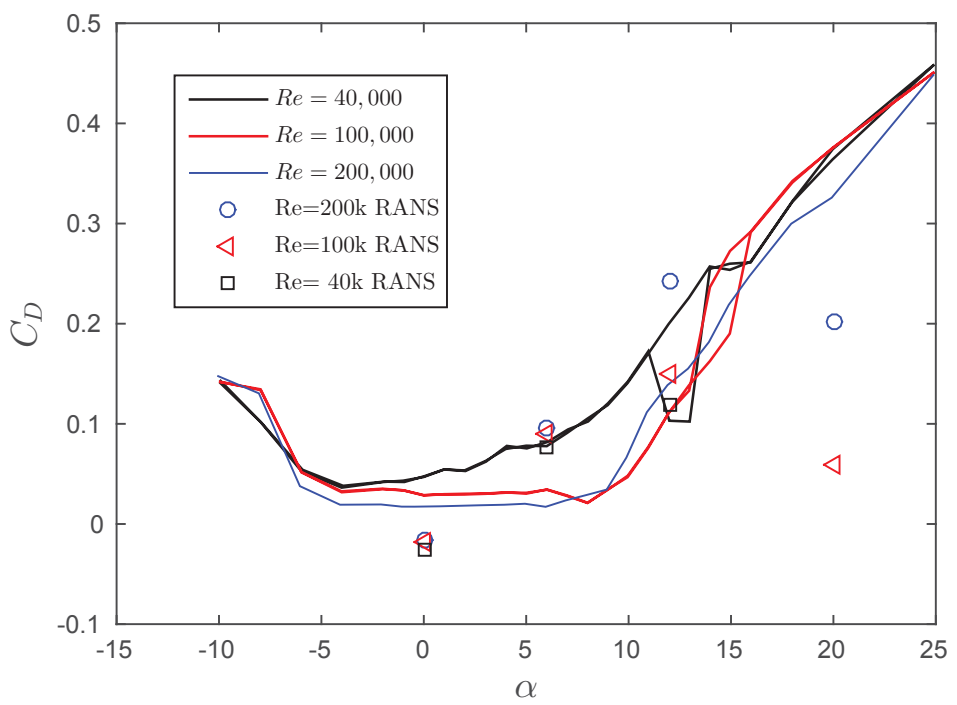

FIGURE 5. Comparison of (time-averaged) drag coefficients with experimental data [10]. Different experimental values at certain AOAs shown by the red and black curves are due to the hysteresis effects of the pitching airfoil.

Figures 6 and 7 illustrate the surface streamlines over the airfoil at $\mathrm{Re}=40,000$ and 100,000, respectively, with an angle of attack of $\alpha=12^{\circ}$. The figures show clearly the formation of 3D spanwise flow structures, demonstrating that the SST model is capable of, at least qualitatively, predicting such structures. These flow structures have also been observed experimentally $[13,4]$. It can also be seen that the stall cells are enhanced by increasing the Reynolds number from 40,000 to 100,000, although such structures are not visible at $\mathrm{Re}=200,000$ (not presented here). Further comparisons between the simulations and measurements are required to assess the capability of RANS turbulence models to predict these flow structures. 


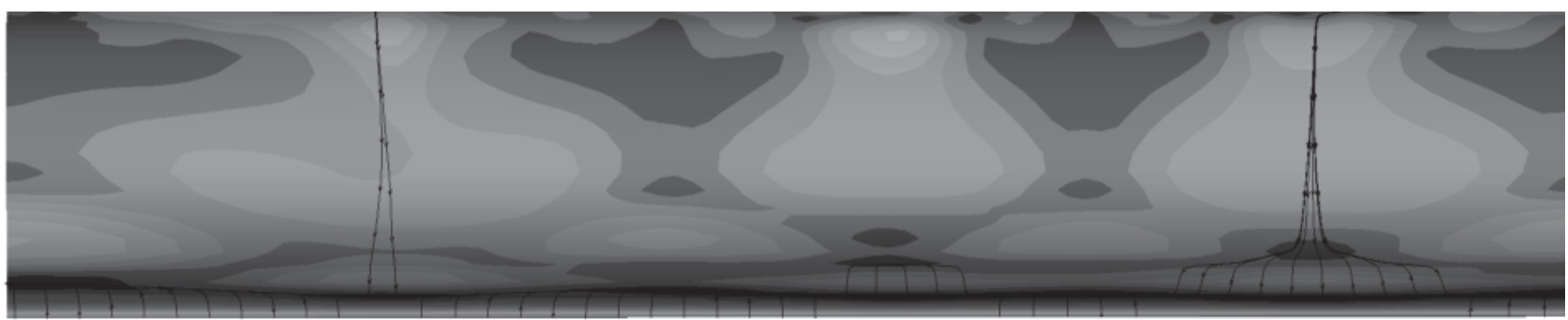

$\operatorname{Re}=\mathbf{4 0 , 0 0 0 )}$

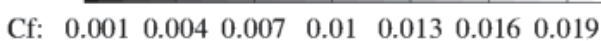

FIGURE 6. Contours of skin friction coefficient and surface streamlines, showing the formation of stall cells on the suction side of the S826 airfoil at Reynolds number 40,000, and angle of attack of $\alpha=12^{\circ}$.

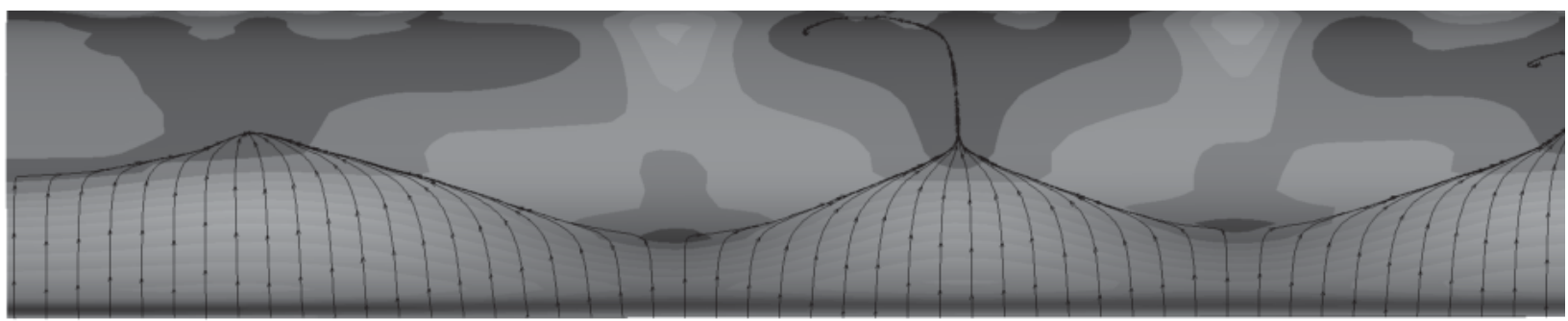

$\operatorname{Re}=100,000)$

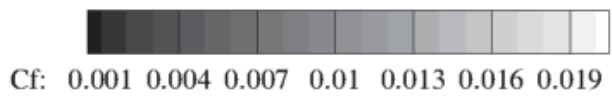

FIGURE 7. Contours of skin friction coefficient and surface streamlines, showing the formation of stall cells on the suction side of the S826 airfoil at Reynolds number 100,000, and angle of attack of $\alpha=12^{\circ}$.

\section{CONCLUSIONS}

This paper presented some preliminary results of unsteady RANS modeling of the flow over an NREL S826 airfoil at three low Reynolds numbers ( $\mathrm{Re}=40,000,100,000$ and 200,000). Computations were performed using the SST k- $\omega$ turbulence model, which was found to have the capability of predicting 3D flow structures (stall cells) over the airfoil at a high angle of attack of $12^{\circ}$. The lift and drag coefficients of the airfoil agreed well with experiments for this high angle of attack where the stall cells were predicted. The presented simulations are part of a more extensive numerical investigation to quantify the capability of unsteady RANS approach to model the formation of laminar separation bubble and stall cell structures, which will be presented in a more detailed future paper.

\section{REFERENCES}

1. H. Hu, and Z. Yang, Journal of Fluids Engineering 130, 051101 (2008).

2. M. Selig, VKI Lecture Series, November pp. 24-28 (2003).

3. H. Horton, Laminar separation bubbles in two and three dimensional incompressible flow., Ph.D. thesis (1968).

4. A. Winkelman, and J. Barlow, AIAA Journal 18, 1006-1008 (1980).

5. M. Manolesos, G. Papadakis, and S. G. Voutsinas, Wind Energy 17, 939-955 (2014).

6. J. Windte, R. Radespiel, S. Scholz, and B. Eisfeld, Rans simulation of the transitional flow around airfoils at low reynolds numbers for steady and unsteady onset conditions, Tech. rep., DTIC Document (2004).

7. H. Sarlak, R. Mikkelsen, S. Sarmast, and J. Sørensen, Journal of Physics, Conf. Series 524, 012027 (2014).

8. M. lin, and H. Sarlak, AIP Conf. Proc. (Accepted) (2015).

9. F. R. Menter, AIAA journal 32, 1598-1605 (1994).

10. H. Sarlak, Large eddy simulation of turbulent flows in wind energy, Ph.D. thesis, Technical University of Denmark (2014).

11. F. Menter, M. Kuntz, and R. Langtry, Turbulence, heat and mass transfer 4, 625-632 (2003).

12. J. Bardina, P. Huang, and T. Coakley, AIAA paper 2121, 1997 (1997).

13. H. Sarlak, A. Frere, P. Chatelain, and J. Sørensen, Journal of Visualization (To be submitted) (2015). 